ment with the predictions we developed in 1993. One of the most encouraging observations is that three of the populations exhibiting the greatest resistance to the SLWF were also high yielding, based on the first year of yield data. We will continue to select for SLWF resistance and improved forage yield. We are hopeful that we will also see a significant increase in yield once we develop populations that exhibit SLWF resistance levels below the assumed economic-threshold level of 2.0.

\section{Conclusion}

Cultural management of the SLWF in alfalfa by either chemical control or cutting management is not feasible. We have developed plant-breeding methodology to successfully select for genetic resistance to the SLWF. Screening is conducted under field conditions in the Imperial Valley during August and September. Seed is produced on the selected plants between September and March in a "winter" nursery in Chile. This permits two generations per year and complete pest and yield evaluation at more than one location starting in the spring after the year of selection. Taking into account both our early predictions and our current progress, we expect that populations with economic resistance to the SLWF will be selected this fall. We are working to provide California growers with resistant cultivars as rapidly as possible.

L.R. Teuber is Professor and K.L. Taggard is Staff Research Associate, Department of Agronomy and Range Science, UC Davis; L.K. Gibbs is Staff Research Associate, Department of Agronomy and Range Science, Desert Research E Extension Center; and M.E. Rupert is former Graduate Research Assistant, Department of Agronomy and Range Science, now Staff Research Associate, Department of Pomology, UC Davis.

The authors wish to express their sincere appreciation to the Imperial Whitefly Management Committee for funding the research reported in this paper.

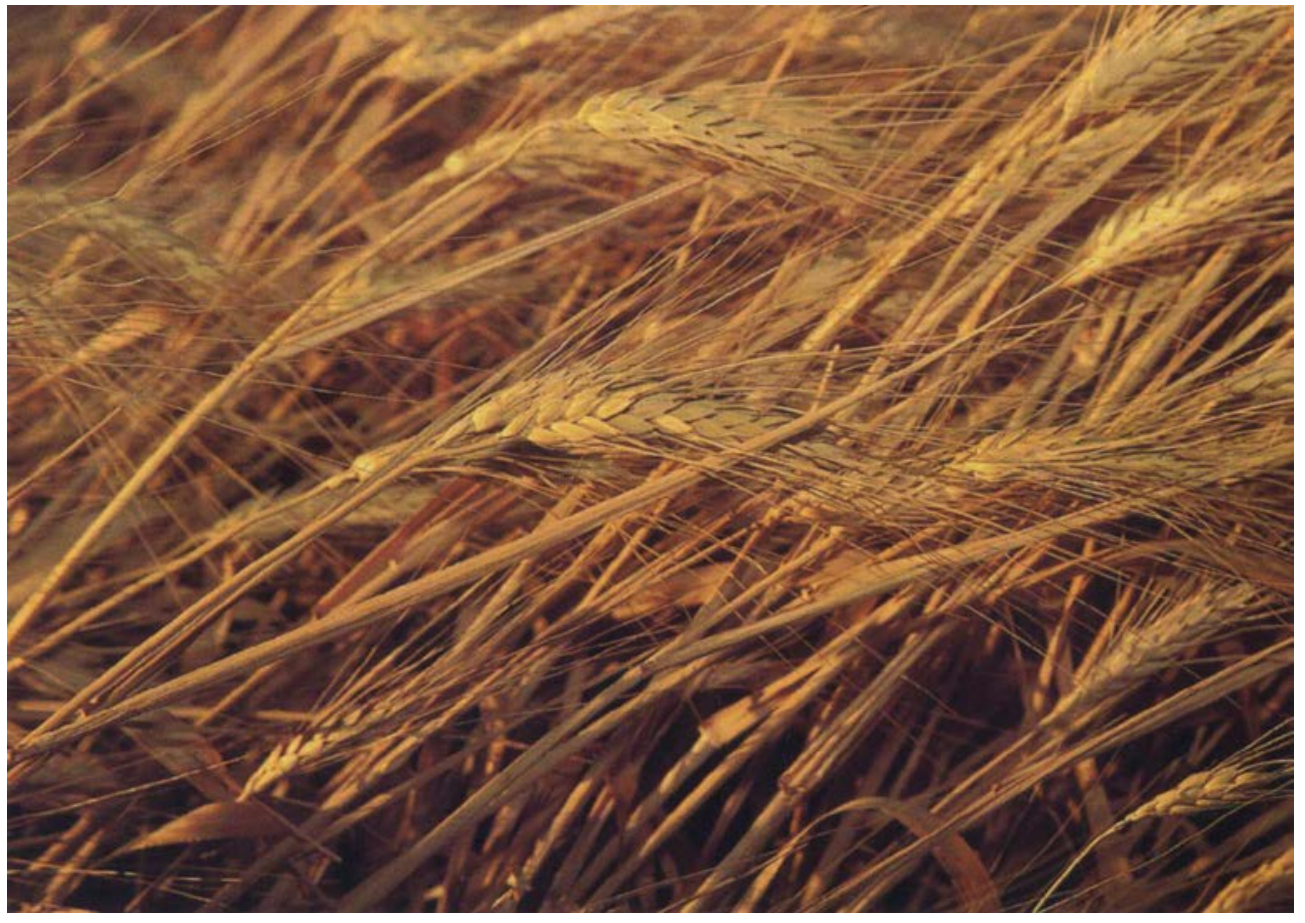

The number of days wheat is susceptible to Karnal bunt depends on the planting date.

\title{
Imperial Valley conditions limit Karnal bunt in wheat
}

\section{Gerald J. Holmes $\square$ Lee F. Jackson $\square$ Thomas M. Perring}

The amount of disease occurring in any given area depends on the presence of the pathogen in sufficient abundance, susceptible hosts and favorable climatic conditions. Each of these factors were severely limiting to the establishment of Karnal bunt (KB) in the Imperial Valley during the 1996 growing season, and none of the 1,476 fields (106,592 acres) tested was shown to be infected with KB. Karnal bunt does not appear to be a threat to wheat production in the Imperial Valley because desert conditions are unfavorable for its development. However, this does not rule out the possibility that low levels of disease may occur occasionally. Assuming that current growing conditions continue and that KBfree seed is planted, the Imperial Valley is at low risk for a $K B$ outbreak.
Karnal Bunt (KB) is a minor disease of wheat that until March 8, 1996, was of little concern to the US grain industry. On that date, scientists at USDA's Agricultural Research Service confirmed the presence of Karnal bunt in Arizona-certified durum wheat seed (cv. Reva), produced near Gila Bend, Ariz. Seed from infested seed lots was planted in Arizona, New Mexico, Texas and California. Fourteen fields amounting to about 960 acres, primarily of the cultivar Kronos, were planted with infected seed in the Imperial Valley of California. As part of a larger effort to prevent the spread of $\mathrm{KB}$, wheat in the Imperial Valley was placed under a federal quarantine. Fields in the quarantine area had to be tested for $\mathrm{KB}$ prior to harvest and again before shipment. All preharvest samples taken from fields in the Imperial Valley (1,476 fields) tested negative for the presence of $\mathrm{KB}$ teliospores. 


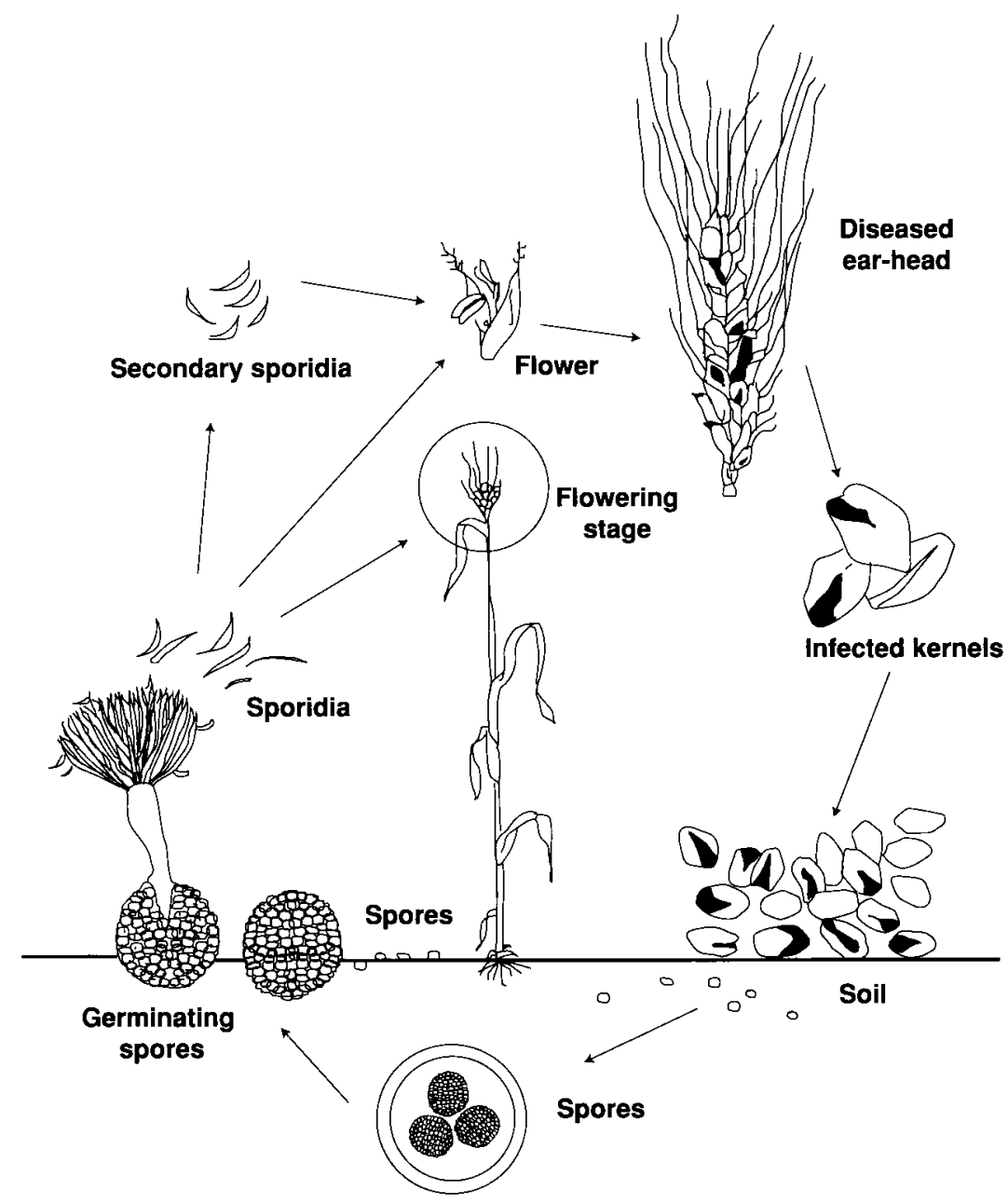

Fig. 1. Life cycle of Karnal bunt infection (Adapted from Joshi et al. 1983).
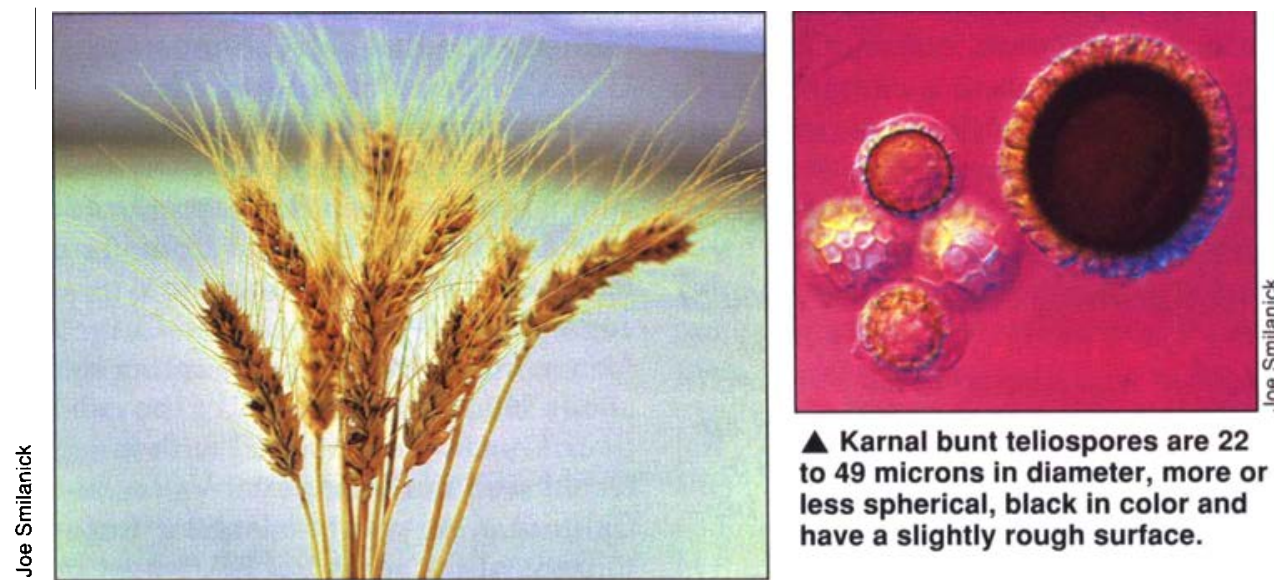

A Karnal bunt teliospores are 22 to $\mathbf{4 9}$ microns in diameter, more or less spherical, black in color and have a slightly rough surface.

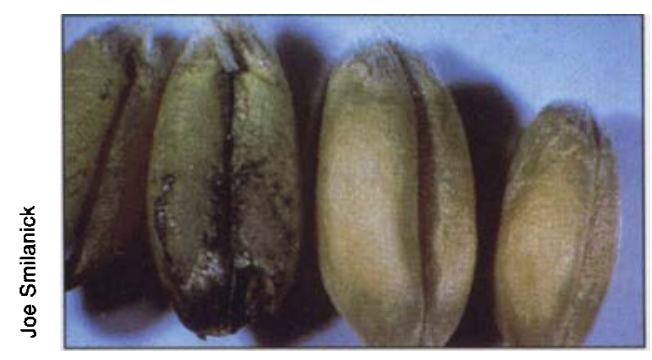

A This wheat spike shows glume spread caused by Karnal bunt infection. In severely infected spikes, the glumes may spread apart near maturity, exposing bunted grains.

Bunted wheat kernels infected with Karnal bunt are usually first noticed in threshed grain.

\section{Distribution and severity}

Karnal bunt is indigenous to India, first being reported near the town of Karnal in 1931. The disease also occurs in Syria, Lebanon, Iraq, Pakistan, Afghanistan and Mexico. It affects common wheat and to a lesser degree durum wheat, triticale and rye. Estimates of loss due to KB are difficult since the disease can reduce seed quality but usually only minimally affects grain yield. Since the disease is seedborne and many countries have a zero tolerance policy, indirect costs are incurred in preventing its spread, while losses in marketing opportunities arise because of its presence. Karnal bunt can be a severe disease, and losses ranging from 5 to $20 \%$ have been reported. However, even during years of severe epidemics in India, the total damage to the wheat crop ranged from 0.3 to $0.5 \%$ of total production.

\section{Symptoms}

Karnal bunt usually is noticed first when broken and/or partially smutted kernels are seen in threshed grain. However, symptoms are present at the soft-dough stage in the form of blackened areas surrounding the base of the zrain, which extend upward along the suture to varying degrees. Unless the disease is severe, only a few florets per spike are affected and diseased spikes are not conspicuous because the zlumes are not distorted by infected kernels. In severely infected spikes, however, the glumes may spread apart near maturity, exposing the bunted grains. Infected grains are irregularly distributed in the spike; some are completely infected, but most are partially infected (hence the alternate common name of the disease, partial bunt). The weight of infected grains is directly related to the severity of infection; as the degree of infection increases, the weight of the grains correspondingly decreases.

While diseased seeds often retain a partial seed coat, the embryo and part of the endosperm can be converted to 


\section{IDA risk assessment pivotal in public policy arena}

masses of small black spores, which emit a fishy odor (due to the presence of trimethylamine) similar to common bunt. Partially bunted seeds often retain their capacity to germinate, and grains with trace-to-moderately-low infections may produce healthy plants.

\section{The causal organism}

Tilletia indica Mitra (syn. Neovossia indica [Mitra] Mundk.) is in the Class Basidiomycetes, Order Ustilaginales, Family Tilletiaceae. Teliospores are 22 to $49 \mu \mathrm{m}$ in diameter, more or less spherical, black in color and have a slightly rough surface. The teliospores are nearly twice the size of those of the related species Tilletia caries and Tilletia controversa, causal organisms of common and dwarf bunt, respectively. The teliospores of KB bear truncate projections surrounded by a delicate membranous sheath.

Germinating teliospores form promycelia and produce numerous haploid, sickle-shaped sporidia (frequently more than 100) in a whorl at the apex. The sporidia do not fuse but germinate directly to form hyphae and/or uninucleate alantoid secondary sporidia, which are forcibly discharged into the air. Primary sporidia have dimensions ranging from 64 to $79 \mu \mathrm{m}$ in length and 1.6 to $1.8 \mu \mathrm{m}$ in width. Secondary sporidia have dimensions ranging from 12 to $13 \mu \mathrm{m}$ in length and about $2 \mu \mathrm{m}$ in width.

\section{Disease cycle}

Sources of inoculum are diseased seed and soil contaminated with spores from previous crops (fig. 1). The delicate pericarp surrounding each sorus of teliospores is easily broken during harvest, dispersing the spores to contaminate the soil. There are no data available to determine the relationship between the teliospore load per seed and subsequent disease appearance in the field. Environment plays a primary role in disease development (Smilanick et al., 1985). The teliospores germinate in response to

\section{Thomas M. Perring}

In April 1996, a quarantine was imposed on wheat grown in Imperial County. The quarantine was supported by a USDA risk assessment that showed an unacceptable threat of a Karnal bunt outbreak from wheat shipped outside the area. Imperial County Agricultural Commissioner Steve Birdsall called UC Riverside Chancellor Raymond L. Orbach to ask for assistance.

In response, Thomas $\mathrm{M}$. Perring, Coordinator of UC's Institute for Desert Agriculture (IDA), assembled a team of scientists representing the County Cooperative Extension Offices in Imperial and Riverside counties and the University's Berkeley, Davis and Riverside campuses. This team set out to conduct a site-specific risk assessment that would take into account the unique circumstances present in the Imperial and Palo Verde valleys. Within 5 weeks, the researchers completed a report that included an analysis of weather conditions in the two valleys vis-à-vis conditions normally associated with Karnal bunt; a risk assessment based on site-specific data; a study of the economic impact on growers in these areas; and recommendations for future research. The risk assessment estimated the probability of spread of Karnal bunt from wheat harvested in the Imperial Valley to be 1 in 1.05 million if the millfeed was not treated, and 1 in 915,358 for the Palo Verde Valley.

Findings from the IDA's report had a major impact on public policy. At Rep. Duncan Hunter's request, Perring and Cindy Giorgio, special assistant to the dean, went to Washington, D.C., to meet with the USDA scientists who conducted the initial risk assessment. They issued a joint statement comparing methods and results and agreeing on a "nearly identical" level of risk. Subsequently, Rep. Sonny Bono introduced an amendment to the 1997 agri- cultural appropriations bill, using the study to request a compensation plan for wheat farmers and handlers and asking USDA to review the study in establishing policy for the 1997 wheat crop. Hunter quoted the report in writing USDA Secretary Dan

Glickman to ask for a modification of the quarantine. In California, the report was featured in a joint hearing of the Senate Committee on Agriculture and Water Resources and the Assembly Agriculture Committee. Discussions also took place between the University and representatives from the California Department of Food and Agriculture.

During a July 17 hearing before USDA, testimony by Hunter, California Farm Bureau Federation president Bob Vice, Imperial County supervisor Brad Luckey and Birdsall drew heavily from the report. The result was a proposal by USDA to remove unnecessary restrictions by lifting the quarantine and establishing "regulated areas." Each regulated field then would be classified according to one of five specific risk categories. In the Imperial Valley, this means that all but 15 fields effectively would be freed from restrictions other than continued testing. On Nov. 4, 1996, the concept of "surveillance areas" was adopted by USDA's Animal and Plant Health Inspection Service.

The IDA study served as an important catalyst for action. Objective, scientific information was the tool decision-makers needed to take the Karnal bunt issue out of the political arena and base their decisions on sound science.

T.M. Perring is Professor, Department of Entomology, and Coordinator for Planning, Institute for Desert Agriculture, UC Riverside; and C.R. Giorgio is Special Assistant to the Dean, College of Natural and Agricultural Sciences, UC Riverside. 
free moisture and produce numerous sporidia at the soil surface that are forcibly ejected and then dispersed by wind, splashing water and insects.

Sporidia have a short life-span, even at high relative humidity (Smilanick et al., 1989), and generally survive for only a few hours when airborne. Long-distance dispersal of secondary sporidia probably can occur only during moist periods and under cloud cover at night. Plants are most susceptible to infection when spikes emerge from the boot, but infection can occur throughout the flowering period. Sporidia infect the ovaries, directly penetrating the glumes and ovary wall. Infection can move across all florets of a spikelet and to the spikelets above and below the initial infection site. Diseased kernels may be partially or completely displaced by masses of teliospores in cool, humid or wet weather. Sporulation starts at the embryo end and moves along the suture of the grain. The extent of kernel bunting depends on when infection occurs and how long favorable conditions last.

Fresh teliospores require a dormancy period of up to 6 months, al-

$\begin{aligned} & \text { Table 1. Estimated days to heading for } 3 \text { durum } \\
& \text { wheat varieties planted on } 3 \text { planting dates at } \\
& \text { UC Desert Research \& Extension Center, } \\
& \text { Holtville }\end{aligned}$
\begin{tabular}{lccc}
\multicolumn{4}{c}{ Days to heading when planted } \\
\hline \hline \\
\cline { 2 - 4 } Variety & Nov. 15 & Dec. 15 & Jan. 13 \\
\hline Kronos & 68 & 63 & 46 \\
Westbred Turbo & 86 & 81 & 64 \\
Yavaros 79 & 79 & 74 & 57 \\
\hline
\end{tabular}

though a low level $(6.7 \%)$ of germination of teliospores from freshly harvested kernels has been observed after 1 week of storage. Teliospores remain viable in the soil for up to 45 months. They survive longer when buried in dry soil than in moist, cropped soils or on the soil surface.

\section{Susceptible period}

In the Imperial Valley, the fields that are most vulnerable to KB are those that were previously contaminated with KB spores, were planted with infested seed or are planted to common wheat (i.e., hard red wheat, which is more susceptible to KB than durum wheat). In 1996, 14 fields ( 960 acres) were planted with infested wheat seed, and all tested negative for $\mathrm{KB}$ teliospores. In the same year, less than 1,000 acres of common wheat were planted in the valley; all of these fields also tested negative. Of the remaining wheat acreage, approximately $90 \%$ was planted with one of 3 durum varieties: Kronos (60\%), Westbred Turbo (20\%), and Yavaros 79 (10\%).

Unlike other smut and bunt fungi, $T$. indica does not infect seedlings. This fungus must infect plants between the beginning of spike emergence and the end of flowering. A conservative estimate of this period for 1996 was Jan. 1 through March 22 for all wheat planted in the Valley. This estimate was derived from data from 1996 durum wheat trials at the UC Desert Research \& Extension Center combined with trials from previous years.

Table 2. Days (from Table 1) and dates to heading, and the estimated Karnal bunt-susceptible period

\begin{tabular}{|c|c|c|c|}
\hline Planting date & Days to heading & Date to heading & KB-susceptible period \\
\hline $\begin{array}{l}\text { Kronos } \\
\text { Nov. } 15 \\
\text { Dec. } 15 \\
\text { Jan. } 13\end{array}$ & $\begin{array}{l}68 \\
63 \\
46\end{array}$ & $\begin{array}{l}\text { Jan. } 22 \\
\text { Feb. } 16 \\
\text { Feb. } 28\end{array}$ & $\begin{array}{l}\text { Jan. 8-Jan. } 29 \\
\text { Feb. 6-Feb. } 22 \\
\text { Feb. 23-March } 4\end{array}$ \\
\hline $\begin{array}{l}\text { Westbred Turbo } \\
\text { Nov. } 15 \\
\text { Dec. } 15 \\
\text { Jan. } 13\end{array}$ & $\begin{array}{l}86 \\
81 \\
64\end{array}$ & $\begin{array}{l}\text { Feb. } 9 \\
\text { March } 5 \\
\text { March } 17\end{array}$ & $\begin{array}{l}\text { Jan. 26-Feb. } 16 \\
\text { Feb. 24-March } 11 \\
\text { March 12-March } 22\end{array}$ \\
\hline $\begin{array}{l}\text { Yavaros } 79 \\
\text { Nov. } 15 \\
\text { Dec. } 15 \\
\text { Jan. } 13\end{array}$ & $\begin{array}{l}79 \\
74 \\
57 \\
\end{array}$ & $\begin{array}{l}\text { Feb. } 23 \\
\text { Feb. } 27 \\
\text { March } 10\end{array}$ & $\begin{array}{l}\text { Jan. 19-Feb. } 9 \\
\text { Feb. 17-March } 4 \\
\text { March 5-March } 15\end{array}$ \\
\hline
\end{tabular}

In the Imperial Valley, wheat is planted between Nov. 15 and March 1. Most is planted between late November and Jan. 1, and in 1996, 71\% was planted before Jan. 1. Due to the heat unit differences between winter and spring, the earlier wheat is planted, the longer its growing season. For example, wheat planted on Nov. 15 required 5 more days to reach heading stage than wheat planted on Dec. 15. Similarly, wheat planted on Jan. 13 required 17 fewer days to reach heading than a Dec. 15 planting. Combining these data with performance data on the three most popular durum wheat varieties grown in the valley, we determined the time to heading as a function of planting date (table 1).

Days to heading is the number of days from planting until $50 \%$ of the spikes are fully emerged (peduncles visible). The period from the beginning of spike emergence (the beginning of the KB-susceptible period) to the completion of spike emergence (heading date) is temperature-dependent and is approximately 5 days for the Jan. 13 planting, 10 days for the Dec. 15 planting, and 14 days for the Nov. 15 planting. The number of days between the heading date and the completion of flowering or anthesis (the end of the KB-susceptible period) is influenced less by temperature, and is estimated to be 5, 6 and 7 days for planting dates of Jan. 13, Dec. 15 and Nov. 15, respectively. Utilizing information in Table 1, along with the above adjustments for days to the beginning of spike emergence and to the end of flowering (period of KB-susceptibility), we estimated the KB-susceptible period to be 10 days, 16 days and 21 days for planting dates of Jan. 13, Dec. 15 and Nov. 15, respectively.

For the three durum varieties, which vary in their time to heading, the KB-susceptible period was calculated for three planting dates (table 2). Taking these as representing the majority of wheat varieties planted, and the three planting dates as representative of the Imperial Valley planting 
times, the KB-susceptible period in 1996 was estimated to begin Jan. 8 and end March 22. To be conservative and accommodate the few earlier wheat plantings, we considered the period of Jan. 1, 1996, through March 31, 1996, as the KB-susceptible period.

\section{Weather (Jan. 1-March 31, 1996)}

Dr. D.V. Singh of the Indian Agriculture Research Institute has collected meteorological data in India during outbreaks of Karnal bunt. These data associate the occurrence of $\mathrm{KB}$ with the following weather parameters (Royer, 1984):

$$
\begin{aligned}
& \text { weekly mean maximum tempera } \\
& \text { tures: } 67^{\circ}-74^{\circ} \mathrm{F}\left(19^{\circ}-23^{\circ} \mathrm{C}\right) \\
& \text { weekly mean minimum tempera } \\
& \text { tures: } 46^{\circ}-54^{\circ} \mathrm{F}\left(8^{\circ}-12^{\circ} \mathrm{C}\right) \\
& \text { weekly mean relative humidity: } \\
& 80 \%
\end{aligned}
$$

Another report (Singh et al. 1983) states, "If at the time of anthesis, the temperature ranges between $67^{\circ}-74^{\circ} \mathrm{F}$ and $46^{\circ}-50^{\circ} \mathrm{F}\left(19^{\circ}-23^{\circ} \mathrm{C}\right.$ and $\left.8^{\circ}-10^{\circ} \mathrm{C}\right)$ coupled with a slight shower providing high atmospheric humidity, the disease gets established very well." In the Imperial Valley, a total of $3 \mathrm{~mm}$ of precipitation fell between Nov. 1 and May 6 ( $1 \mathrm{~mm}$ in mid-February and 2 $\mathrm{mm}$ in early March). Other studies note "the high incidence of the disease ... when the temperature ranges from $64^{\circ}-73^{\circ} \mathrm{F}\left(18^{\circ}-22.5^{\circ} \mathrm{C}\right)$ and relative humidity is above $70 \%$ " (Aujla et al. 1977). While these weather data are very general, they provide some measure for comparison with the 1996 Imperial Valley weather conditions.

The KB-susceptible period was shortened by rising temperatures in the Imperial Valley beginning around March 1. During this period, temperatures were in the upper 70 s to low 80 s (higher than Singh's maximum range) and maximum relative humidity was between 65 and $75 \%$ (lower than Singh's reported humidity requirement). Perhaps more important than maximum and minimum temperatures was the duration of temperatures

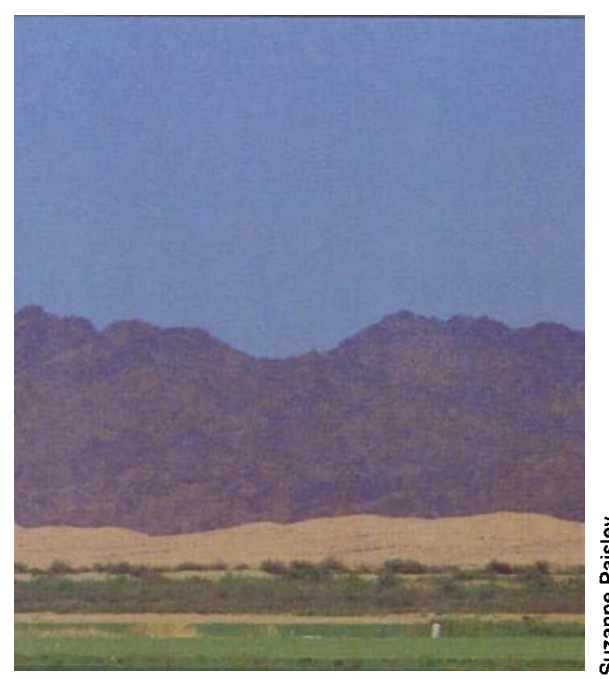

Karnal bunt is associated with a maximum temperature of $74^{\circ} \mathrm{F}$ and relative humidity higher than $80 \%$. In 1996 , these conditions rarely persisted longer than $\mathbf{2 4}$ hours in the Imperial Valley.

and humidities. Daily temperatures on Jan. 28 and 30, Feb. 1, 2, 3, 10, 11, 12 and 21, and March 4, 5, 12 and 13 fell within the temperature range associated with KB reported by Singh et al. (1983). Of these dates, maximum humidities were above $70 \%$ on Jan. 28 and 30, Feb. 1, 2, 3, 10, 11 and 12, and March 13. Minimum relative humidities on these days always dipped below $70 \%$, the minimum humidity associated with $\mathrm{KB}$ reported by Aujla et al. (1977). Rain fell in the Imperial Valley only on Feb. $12(1 \mathrm{~mm})$ and March 1 $(2 \mathrm{~mm})$. Even considering the microclimatic conditions at the soil surface created by irrigated cropping systems, we conclude that conditions required for $\mathrm{KB}$ to occur rarely persisted longer than 24 hours in the Imperial Valley in 1996.

\section{Summary}

The amount of disease occurring in or on any host is dependent upon the presence of the pathogen in sufficient abundance, a favorable environment and a susceptible host. For Karnal bunt of wheat in the Imperial Valley, all three factors were at a minimum in 1996. The amount of pathogen introduced was limited to a small number of spores on wheat used to plant 960 acres, and the weather conditions, planting dates and varieties were not conducive to teliospore germination.
Considering the conditions that must be met for $\mathrm{KB}$ disease development, it is not surprising that $\mathrm{KB}$ is a minor disease even in areas where it is endemic. While it is not impossible for KB to occur in the Imperial Valley, the probability of its occurrence is very low.

G.J. Holmes is former Imperial County

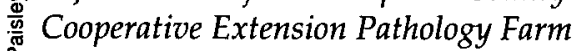
Advisor, UCCE Imperial County, and currently Professor and Extension Plant Pathologist, Department of Plant Pathology, North Carolina State University, Raleigh, N.C.; L.F. Jackson is Extension Agronomist, Department of Agronomy and Range Science, UC Davis; and T.M. Perring is Professor, Department of Entomology and Coordinator for Planning, Institute for Desert Agriculture, UC Riverside.

\section{References:}

Aujla SS, Sharma K, Chand K, Sawney SS. 1977. Influence of weather factors on the incidence and epidemiology of Karnal bunt of wheat. Indian J. Ecol. 8: 175-9.

Joshi LM, Singh DV, Srivastava KD. 1983. Karnal bunt: A minor disease that is now a threat to wheat. The Botanical Review 49:309-30.

Royer M. 1984. Travel to India to review Karnal bunt research. USDA, North Atlantic Area Plant Disease Research Lab. May 30, 1984.

Singh DV, Joshi LM, Srivastava KD. 1983. Karnal bunt - A new threat to wheat in India. Recent Advances in Plant Pathology. Print House (India) Lucknow: 121-35.

Smilanick JL, Hoffmann JA, Royer $\mathrm{MH}$. 1985. Effect of temperature, $\mathrm{pH}$, light, and desiccation on teliospore germination of Tilletia indica. Phytopathology 75: 1428-31.

Smilanick JL, Prescott JM, Hoffmann JA, Secrest LR, Wiese K. 1989. Environmental effects on survival and growth of secondary sporidia and teliospores of Tilletia indica. Crop Protection 8: 86-90. 